\title{
SPTBN1 wt Allele
}

National Cancer Institute

\section{Source}

National Cancer Institute. SPTBN1 wt Allele. NCI Thesaurus. Code C132082.

Human SPTBN1 wild-type allele is located in the vicinity of 2p21 and is approximately 215 $\mathrm{kb}$ in length. This allele, which encodes spectrin beta chain, non-erythrocytic 1 protein, is involved in the modulation of both cell shape and calcium-dependent secretory pathways. 